\title{
ROME CONFERENCE ON THE RULE OF LAW IN AFGHANISTAN (July 2-3, 2007)
}

JOINT RECOMMENDATIONS

The Participants to the Rome Conference on Justice and Rule of Law recommend that the following goals, underlying principles and key actions form the basis of the conclusions of the Conference:

Key Goals

Recalling the framework for rule of law and justice reform provided by the Afghanistan Compact and its benchmarks, based on the vision of "Justice for All" and within the overall framework of the Afghanistan National Development Strategy (ANDS):

The Government of the Islamic Republic of Afghanistan

Commits itself to finalize a national justice sector strategy and to implement comprehensive rule of law reform with the assistance of the International Community through a national justice programme.

The donors and the international community

Pledge significantly to increase coordinated support for rule of law reform in Afghanistan, based on the national justice programme put forward by the Government of the Islamic Republic of Afghanistan.

Shared principles

The above-mentioned goals are based on the following underlying principles that the Government of Afghanistan and the representatives of the International Community share:

- Establishing effective rule of law throughout Afghanistan will require long term commitment as well as planned and structured financial investment encouraging sustainable institutional development.

- Rule of law programming should be based on reasonable expectations and should be consistent with Afghan needs and realities.

- Rule of law funding mechanisms should be consistent with the Paris Declaration on Aid Effectiveness and the Afghanistan Compact and make use - as much as possible - of country systems, particularly the national budget.

- The effectiveness and sustainability of rule of law reforms require improving the credibility, integrity and professionalism of the justice institutions through the establishment of professional standards, codes of conduct using an objective and transparent accountability mechanism.

- Credible rule of law initiatives embrace and engage Afghan legal context, culture, customs and the Islamic foundation of the legal system of Afghanistan

- Rule of law reform should strive towards international standards and strengthen respect for human rights as provided for in the Afghan Constitution

- Targeted, standardised and defined monitoring and evaluation are essential in maintaining focus and direction in rule of law reform. 
Key actions

As concrete steps towards the achievement of the above mentioned key goals, the Government of the Islamic Republic of Afghanistan and the International Community:

i. Agree on the priorities for the Justice Sector reform as defined by the Afghan Justice Institutions and presented in Rome in the Government's Justice Sector Priorities.

ii. Establish a comprehensive National Justice Programme under the leadership of the Supreme Court, the Ministry of Justice and the Attorney General's Office on the basis of the strategies presented at the Conference. The National Justice Programme shall be comprehensive and credible, including specific plans for short-, mid- and long-term implementation and a mechanism for review.

iii. Decide to establish a mechanism for pooled donor funding and management for the National Justice Programme, along with bilateral assistance. In this regard, the Conference invites the World Bank together with other international organisations to assist the Government in the development of the National Justice Program, by suggesting a design for the funding mechanism and upgrading the financial management capacity of the justice institutions. The Conference notes that a mechanism financed under the ARTF structure shows the most potential in this regard.

iv. Endorse a Donor Implementation Plan including

a. Pledging of immediate support based on concrete and prioritized short term projects submitted by the Government of the Islamic Republic of Afghanistan to the Rome Conference;

b. Pledging of long-term support and commitment to long-term and coordinated funding for the National Justice Programme, to be finalized in the framework of the ANDS and as a follow up to the Rome Conference by March 2008;

c. Establishment of a Provincial Justice Coordination Mechanism, to enhance coordination of assistance to the justice sector and rule of law reform in the provinces. The programming for the justice sector reform in the provinces is to be done in line with the overall strategy, whilst the mandate for the Provincial Justice Coordination Mechanism (PJCM) is detailed in a planning document submitted for the consideration of the Rome Conference.

v. Establish an Afghan-led effective and comprehensive monitoring and evaluation system for the justice sector under the ANDS Secretariat and the JCMB. Details of the monitoring mechanism are provided in the planning document submitted for the consideration of the Rome Conference..

vi. Launch a process to assist the Government of Afghanistan to effectively link coordinated donor support to the National Justice Programme. The steps following the Rome Conference will include the following actions:

a. At Rome (July 2007) - Presentation of a brief donor support plan and pledging for a preliminary list of key projects for the Supreme Court, Ministry of Justice and Attorney General's Office to be funded through immediate support;

b. Immediately after Rome (August - September 2007) - Elaboration of a comprehensive and credible National Justice Programme that links the Supreme Court, Ministry of Justice and Attorney General's Office ANDS Strategies and is funded through a coordinated donor mechanism;.

c. Kabul meeting for the presentation of the National Justice Programme (October 2007) - the Rome Conference creates a momentum on rule of law reform through 
commitments and pledging which are to be supported through a steady process of elaboration of the National Justice Programme that is Afghan-led and builds on the ANDS process.. In the aftermath of Rome a meeting will take place in Kabul to link the presentation of a comprehensive National Justice Programme with the priorities defined by national institutions and the commitments expressed in Rome .

d. Subsequent Meetings (November to March 2008) - By March 2008 and under the ANDS Secretariat and in close collaboration with the Ministry of Finance, with the assistance of the World Bank and the donor community the National Justice Programme will be established and the donor commitment defined in relation to the modalities and management of funding mechanism selected for the Programme's implementation.

vii. Agree to implement the recommendations produced by the panels and the other working sessions, which have taken place at the Rome Conference on Rule of Law in July 2 and 3, 2007. 
a) Key issues common to the three justice institutions' strategies that need to be addressed at BOTH national and provincial levels:

- Salary support: there is a need for pay and performance reform for justice officials to improve performance, mitigate corruption and ensure professional qualification.

- Infrastructure and office equipment: Subject to survey of essential work to be targeted.

- Transportation: Subject to survey of essential work to be targeted.

- Operating costs need to be financed to improve performance of justice institutions

- Capacity building and training: Establishment of formal qualification and continuing professional development requirements

- Information management and human resource management to be established

- Codes of Ethics and oversight mechanisms to be established for all legal professionals

- Financial management. The justice sector is currently characterized by inadequate budgets and low budget execution rates, mostly due to serious capacity constraints in this area.

- Public awareness: There is a need to develop tools and instrument which ensure access at all level of society, in particular when the target of legal education is the wider public. Different media tools should be discussed.

b) Additional and thematic gaps and challenges emerged from the Institutional Strategies (see background papers for further details):

\section{Legislative process}

- Address the capacity building and resource needs of the Taqnin

- Improve legal translation capacity of the Government's Agencies

- Provide library and research capabilities to the drafters

- Improve the quality of legislative process

- Improve public awareness of legal rights and responsibilities

\section{Institutional Strategies and Coordination}

- Improve data collection, monitoring and information management

- Establishment of compatible computerized and database systems

- Establish reliable storage and retrieval of court records

- Encourage better computerization of laws and jurisprudence

- Promote cooperation between AGO and MOI/Afghan National Police

- Ensure coordination amongst all Justice Institutions

- Establish oversight mechanisms on the National Directorate of Security (NDS)

- Develop coordinated public awareness campaigns

- General lack of focus and training on civil law issues particularly property law

- Efforts should be made to bring Afghan administrative law in line with Afghan constitutional principles as well as international standards, by reinforcing the general administrative law frameworks and judicial oversight; other non-judicial accountability mechanisms could be considered.

- Set the foundations for international judicial cooperation capabilities

\section{Capacity building, legal education and training}

- legal education should be combined with an obligation of ongoing professional development for practitioners;

- Develop the capacity of the National Legal Training Center "NLTC";

- Capacity constraints in planning, budgeting and financial management;

- Establish General training principles and standards;

- Enhance Professional staff quality;

- Administrative and support staff quality; and

- Support the Law and Sharia faculty of higher education institutions. 


\section{Legal aid, access to justice and human rights}

- Expansion of legal aid services throughout the country;

- Women's access to justice, particularly concrete alternatives to detention for women in conflict with justice;

- Land and property rights, specifically the need for an effective system of registration and dispute resolution;

- Address issues of detention, due process, accountability, transparency of the justice system and law enforcement agencies, including the National Directorate of Security (NDS)

- Transitional Justice;

- Relation between formal and informal justice and the development of a national policy on the informal justice system.

\section{Cross cutting issues}

- Counter-narcotics

- Anti-corruption

- Gender mainstreaming

- Monitoring and evaluation 